\title{
Doing histories of education and psychology
}

\author{
Haciendo historias de la educación y \\ la psicología
}

\section{Faire les histoires de l'éducation et de la psychologie}

\section{Kari Dehli}

OISE, University of Toronto, Canada

\begin{abstract}
This paper examines changing relations between education and psychological knowledge about children. I discuss some of the ways in which relations between education and psychology have been approached in historical research in education, ranging from social history to genealogical approaches, influenced Michel Foucault. Rather than viewing these approaches as mutually exclusive, I suggest that they can enrich each other. I illustrate this argument by tracing how two kinds of psychology - mental measurement and child study - constructed the child as object in the practice of psychologists working at the University of Toronto in the first half of the twentieth century.
\end{abstract}

Key words: education, psychology, Foucault, mental measurement, child study.

\section{RESUMEN}

Este artículos analiza las relaciones cambiantes entre el conocimiento educativo y psicológico de los niños. Planteo algunas de las formas en que las relaciones entre educación y psicología han sido abordadas en la investigación en historia de la educación, oscilando de la historia social a los acercamientos genealógicos, influenciados por Michel Foucault. Más que observar estos acercamientos como mutuamente exclusivos, considero que pueden enriquecerse el uno al otro. Ilustro este argumento dando seguimiento a cómo dos tipos de psicología, la centrada en las mediciones mentales y la centrada en el estudio del niño, imaginaron el niño como objeto en la práctica de los psicólogos que trabajaban en la Universidad de Toronto en la primera parte del siglo XX.

Descriptores: educación, psicología, Foucault, medición mental, estudio del niño. 


\section{RÉSUMÉ}

Cet article examine la relation entre l'éducation et le savoir psychologique sur les enfants. J'examine comment certaines façons dont les relations entre l'éducation et la psychologie ont été abordées dans la recherche historique en éducation, à partir de l'histoire sociale jusqu'aux approches généalogiques, ont influencé Michel Foucault. Au lieu de regarder ces approches comme s'excluant mutuellement, je suggère qu'elles peuvent s'enrichir les unes les autres. J'illustre ces arguments en traçant comment deux sortes de psychologies - mesures mentales et étude de l'enfant - ont construit l'enfant comme objet dans la pratique des psychologues qui ont œuvré à l'université de Toronto durant la première partie du vingtième siècle.

Mots clés: l'éducation, psychologie, Foucault, mesure mentale, étude de l'enfant.

$\mathrm{T}$ HE BRAINS OF YOUNG CHILDREN HAVE BECOME THE FOCUS of a great deal of attention in recent education research and debate. With reference to advances in neuroscience and the visualizing possibilities of digital technologies, researchers and some policy-makers assert that children's brains are 'hard-wired' at an early age, and that children as young as 2 or 3 should be brought into educational environments where their potential for learning and development can be stimulated (McCain \& Mustard, 1999). To do otherwise, some argue, is tantamount to child neglect, a neglect that will not only have negative effects on the individual, but entail significant future social and economic losses for the nation, as well. In discourses that blend neuroscience, culture, and economics, the human is viewed as not simply having a brain, but as 'being a brain' (Gazzaniga, 2005, p. 31, as cited in Vidal, 2009, p. 6). 'Brain research' is thus having a growing impact in many social spheres, not least in education, where it is not only mobilized in support of early childhood education (Ontario Ministry of Education, 2013; Pascal, 2009), but also to argue for differentiated programs and teaching strategies tailored to individual students' brain capacities and aptitudes.

Contemporary representations of children's brains might be novel, impressive, or frightening in their display of digital imaging and colourful depictions of cerebral functions. However, the young child and the capacities and functions of its mind or brain have figured in educators' imagination for more than a century (Bruer, 1999; Lee \& Motzkau, 2011). Whether viewed in the context of observations in the family, laboratory or school, through surveys of parents and responses to stimulations or tests, researchers and educators have engaged in intense arguments about how to identify and unlock the secrets and potentials of 'children's minds' (Donaldson, 1979). ${ }^{1}$

How might it be possible to write histories of such ideas and the effects they have had? In this paper I want to think about how the minds or brains of children came to be viewed as such important objects of knowledge and targets of educational intervention. I will focus on changing relations between education and psychological knowledge about children, and situate the discussion in relation to the work of psychologists working in Toronto in the first half of the twentieth century. I discuss some of the ways in which relations between education and psychology have 
been approached in historical research in education, ranging from social history to genealogical approaches, influenced Michel Foucault. Rather than viewing these as mutually exclusive, I suggest that they can enrich each other, starting with questions about phenomena in the now - such as the emergence of the child's brain as object of knowledge and intervention - and then use concepts and questions from several approaches that can open up interesting ways of seeing how they came into being. I am not so interested in erecting boundaries between approaches to doing history or in policing methods or questions that can or cannot be asked through them. ${ }^{2} \mathrm{I}$ illustrate this somewhat eclectic approach by tracing two examples of how the child was constructed as an object of knowledge and target of intervention, drawn from research of children conducted by psychologists working in Toronto in the first half of the twentieth century. One strand of research foregrounded 'mental measurement,' while the second was concerned with 'child study.' The final section of the paper offers tentative answers to some of the 'so what' questions that might be raised: What difference does it make to approach history of education in these ways?

Much of the history of psychology's relations to education has been organized around binaries that bring to bear historians' conceptions of, and positions within, contemporary debates about the role of education and educators in social reform and individual development. ${ }^{3}$ In my own thesis research, conducted in the 1980s, I drew on approaches from social history and historical sociology to tease out the social interests and power relations at work in my research site, the City of Toronto's public schools, and Home and School Associations organized in relation to them (Dehli, 1988). While not a historical biography, my study identified particular individuals and organizations whose actions seemed to make things happen, or whose interests were represented or secured in and through schooling. I aimed to identify prevailing ideologies and conditions, layering my arguments with accounts of class conditions and gender relations, and I was interested in how women's work in education reform organizations was part of processes of state formation (Corrigan \& Sayer, 1985). To build these kinds of arguments, I combed archival sources, piecing together accounts based on reading of organizational records, newspaper clippings, research reports, and letters.

The density of traffic among women's organizations, the Toronto Board of Education, and the nascent Psychology program at the University of Toronto was striking. The subjects at the centre of my research - middle class women who used Home and School Associations as instruments of education reform and as tools for maintaining, and occasionally challenging, class and gender relations in education were intensely engaged with emerging forms of social and psychological science and expertise. The circulation and 'take-up' of scientific discourses were made evident in women's mobilization of arguments furnished by experts whose publications they read, or whose lectures they heard. It was also quite striking how causes of many of the social problems of the day came to be linked to the individual, and how ideas about social and educational problems and their amelioration through individual improvement travelled. During the first half of the twentieth century, middle-class women were actively involved in both local and international networks circulating 
new educational knowledge, including the emerging discipline of psychology, and psychology of the child in particular. Thus social and education reformers in Toronto were connected in various ways to organizations in the United States and Britain: they attended conferences and exchanges, read and cited scientific journals, and modeled social investigations of schools and neighbourhoods upon studies carried out in American cities (Hareven, 1969). As well, in cities across North America, local and central governments grew rapidly, in part to build and administer schools, to train teachers, and organize the instruction of children. Psychology emerged as a discipline during this period, and one of its sub-disciplines, child psychology, circulated through these kinds of relations and networks, as it was fashioned to identify and respond to some of the numerous problems that arose in the process of 'assembling the school' (Hunter, 1996).

Much of this history is familiar and Canadian historians have pursued different aspects of it, often drawing on social history approaches to do so. ${ }^{4}$ In these accounts, as in my own, the activities and experiences of individuals and organizations were situated in relation to broader social and economic relations. Archival sources and public documents were analyzed to reveal the social interests they might represent, often framed in terms of ideology. Other historical accounts take a different approach to language and discourse, and focus on how 'the child' was brought into the centre of social and education reform through discursive practices (Richardson, 1989). Moving beyond notions of representation and ideology, Nikolas Rose (1985) for example, draws from Foucault to argue that a large and multi-faceted apparatus of discourses, institutions, techniques, and practices brought 'the child' into scientific knowledge for the first time. ${ }^{5}$ Here language, or discourse, assumes a more central and productive role in the constitution of knowledge and power. Psychology was central to this process, as diverse research programs and questions became organized as a recognizable discipline by generating, and policing adherence to, consistent methods of observation, categorization, reporting, and representation (Danziger, 1997). Valerie Walkerdine has suggested along similar lines that psychological knowledge of children was not imposed on schools from without. Rather, the emergence of psychology as a discipline, and child development in particular, was implicated in the construction and growth of mass compulsory schooling, an integral part of the pedagogical practices that schooling required. Schooling created new problems of the social and the individual, problems for which psychology sought to supply definition and meaning, while at the same time offering strategies for intervention and amelioration (Walkerdine, 1984).

These ways of analyzing the historical relationships between child psychology and education offer many important insights that can take us beyond the identification of historical agents or social interests. Walkerdine and Rose are both interested in asking 'how' questions: how psychological phenomena come into being, how methods of surveillance and observation are devised and used, and how techniques of government and self-government are crafted in response to problems of social administration and management. Their accounts generate questions of how knowledge about, and strategies for intervening in, children's lives and education were produced and 
circulated among education and social reformers, perhaps generating different effects in different settings. Their questions allow us to examine how social arrangements and identities we take for granted in the present have come into being, and to wonder how social life - and education - could have been otherwise. ${ }^{6}$

Ian Hunter draws from Foucault's work to provide a more pragmatic view of the history of schooling, where its formation, organization, and operation are analyzed in terms of its practices rather than (presumed) principles. In his view, the school is an "assemblage," or an "improvised historical institution," rather than the failed attempt to realize the principle of complete personal development (or any other principle), or an instance of ideological domination. The school, he argues, is "capable of nothing more than contingent solutions to limited problems" (Hunter, 1996, pp. 147-148). In this account, schools do not adopt practices - such as those that sought to identify intelligent or abnormal children - in order to serve particular social interests. Rather, it is a matter of improvising techniques and rationales that can support more efficient management of complex problems and populations.

Historical sociologist Bruce Curtis makes a different argument. While his studies of education state formation in 19th century Canada makes use of Foucault to examine the professionalization of school inspectors, the emergence of school bureaucracies, and the organization of the census, he does not view these knowledge-making practices and organizational developments merely as matters of "technical necessity." Quite the contrary, he suggests that such as view obscures the political interests of bureaucratic cadres and state servants, while it ignores or overshadows the specifically educational elements of bureaucratic arrangements themselves. No bureaucracy can function unless those subject to it adopt specific attitudes, habits, beliefs, and orientations - attitudes toward authority; habits of punctuality, regularity, and consistency; beliefs about the abstract nature and legitimacy of authority and expertise; orientations to rules and procedures (Curtis, 1992, p. 174).

Curtis goes on to observe that "authority has a cultural basis," and his work examines how the authority to know the lives of others shifted from being the prerogative of dominant class men in the mid-19th century to being vested in 'disinterested' bureaucracies, administrative procedure, and expertise, and a "proliferation of impersonal forms of state knowledge" (p. 176). One effect of the shift from amateur to expert observation, according to Curtis, is that dominant class interests are folded into, or become naturalized as, the public interest.

I have found the lines of analysis drawn from Foucault's approach to power, knowledge, and discourse very productive for my own historical and sociological research. But, like Curtis, I do not want to abandon questions raised in social history - who does what to whom and why. It seems to me that we need these kinds of questions as well, in order to tease out dimensions of social inequality and struggle in the history of schooling. In a paper tracing the generation, organization, and use of student records as a particular form of governmental knowledge in 19th and 20th century Birmingham schools, Ian Grosvenor and Kevin Myers offer one example of such an account. They agree with Foucault that claims to know the child, its intelligence level, background, and so on were also claims to power. That is, the pursuit 
of knowing 'the child' imposed meaning and identity (Grosvenor \& Myers, 2006). And, they are also interested in those who introduced and those who were the targets of these impositions. Grosvenor and Myers therefore argue that practices of gathering and organizing student census records (in their case the city of Birmingham, England) were especially consequential for working class and poor students, whose school attendance and classroom conduct were being identified as a particular problem by teachers and administrators. They argued that such knowledge claims are productive, and knowledge generated in and through schooling might be especially effective in constituting new forms and norms of subjectivity, such as the normal child, the pupil, the developing child, and the high achiever, along with others: the feeble-minded, the defective, the slow and so on. At the same time, emerging forms of empirical knowledge of the social, such as surveys and statistical processes, generated norms and measures for social administration and governance that framed populations as well as individuals, and differentiated categories within them in terms of improvement, progress, and effectiveness.

I will now draw from this discussion to think about how we might write histories of child psychology in education. The dense traffic between the university, school board, and local reform organizations in Toronto offers one indication of how schools were deeply implicated in the generation of new sciences of the individual and the social. Over the course of the first half of the twentieth century, the relations among these sites came to be formalized, as claims to expertise were consolidated within, and elaborated by, the university. Schools were (and are), along with families, key 'surfaces of emergence' of problems demanding attention from authorities and experts (Scheurich, 1994). In conditions of rapid urbanization and migration, Toronto's poor children emerged as a particular kind of problem, and as particular kinds of objects of knowledge and subjects of education, recognizable in terms of their difference in relation to educational norms constructed through new expert knowledge. During the early decades of the 20th century, these children and their bodies, minds, and conduct in and out of school - as well as their families, neighbourhoods, cultures, and 'races' - were brought into view by a range of sometimes competing methods of observation, and 'assembled' through various knowledges as particular kinds of subjects (Burman, 2005). In this context the production of medical and psychological knowledge, and the process that Patrice Milewski (2010) calls the 'scientisation of schooling,' were especially important. Psychological knowledge and expertise played crucial roles in this 'scientisation' process, not only through the more obvious ways in which poor and racialized children were categorized and differentiated, but also in the ways that norms were generated through the observation of middle class and white children. Such observations were, in turn, organized and mobilized through the routine work of teachers, as they compared the behavior and accomplishments of students in their care to each other, and in relation to charts enumerating normal 'stages of development' (Walkerdine, 1993). Based on the observations of the children of professional middle class families, institutions such as the Toronto Institute for Child Study played a major role in producing devices by which teachers (and parents) could organize their observations (Varga, 2011). 
From the late 19th century, middle class women volunteer visitors, as well as visiting teachers and nurses, ventured into poor neighbourhoods in Toronto, New York, and Chicago to observe housing conditions, family life and parenting, children's health, and school attendance, among others. The settlement house movement in the three cities provided important organizational leadership and support for this form of social inquiry; their accounts of children living in crowded and unsanitary conditions, and streets strewn with garbage, were used to mobilize and advocate for governments to improve housing and sanitary conditions, provide clean drinking water, and to organize health clinics, serve milk to school children, or to build playgrounds (Addams, 1912). Visitors' accounts were also used to argue for education programs to teach women, particularly poor immigrant mothers, about baby-care, cooking, home-making, and so on (Dehli, 1990, 1996). Local campaigns to improve living conditions among the urban poor, particularly poor children and mothers, ranged from concrete measures to address inequality, unemployment, and low wages, to attempts to improve the poor themselves. Another important form of intervention was to incorporate kindergarten programs in urban schools located in poor neighbourhoods, as well as day nurseries in neighbourhood centres. Home visits were integral to these initiatives, and reports of such visits were part of the daily tasks of kindergarten teachers and settlement workers. Economic necessity and moral scrutiny mingled in visitors' reports and in debates about whether, how, and how much local governments and schools ought to intervene in poor people's lives. Moreover, mothers raising children in poverty were subjected to particular scrutiny, as psychologists argued that the quality of mothering was vital to children's well-being and future livelihoods. Thus, poor women's lives - their habits and character, their domestic skills, their relations with men, as well as their childrearing practices - were increasingly subjected to observation and intervention.

Visiting nurses thus made working class and poor women and children visible as 'social problems,' and their reports helped build an archive of knowledge that entered into the management of school, health, and welfare departments. However, beyond noting incidences of particular afflictions and proposed treatments, nurses' records retained some of the character of the reports compiled by earlier generation of volunteer women visitors. They were anecdotal, subjective, and frequently explicit in their moral judgments, and they were rarely analyzed by way of statistical methods. They did not lend themselves to systematic comparison and correlation, and therefore lacked the persuasive power of another emerging discipline, psychology, and particularly its development of 'mental measurement,' intelligence testing, and statistics (Milewski, 2010; Paterson, 1989; Rose, 1979).

The appearance of children who failed, or refused, to 'adjust' to teachers' expectations and discipline presented particular challenges of school management and administration. School administrators in Toronto, and elsewhere, welcomed the new expertise of psychologists to find ways to identify the causes and find solutions to these problems. A series of research projects between the city's public school board and the University of Toronto's nascent psychology program were organized in the late $1910 \mathrm{~s}$ and lasting into the 1950s (Pols, 2002). In the first phases of this collaboration, it 
is important to note that attention did not focus exclusively on children as individuals, but rather situated them in the contexts of classrooms, schoolyards, and homes. Moreover, the researcher widened its scope beyond students exhibiting 'defects' to encompass the school population as a whole.

One of the earliest research projects conducted in a Toronto elementary school was undertaken by a team of psychologists of the University of Toronto and the Canadian National Committee for Mental Hygiene. Results of the study were published in the third issue of Committee's journal, Canadian Journal of Mental Hygiene, in 1921 (Pratt, 1921). ${ }^{7}$ The lead author of the study was E. J. Pratt. The study shows the close association of psychology, medicine, and education in the early 20th century and also reveals how a range of methods of observation were brought together, including mental measurement, narrative observations (similar to those assembled by nurses and women volunteers), sociological data (such as income levels, religion, and ethnicity), and statistics. With teachers recruited to administer intelligence tests to students, the project is also an example of how schools and psychologists collaborated to produce scientific knowledge.

Pratt and his team were hopeful that the new technology of 'intelligence testing,' in combination with observations and family histories, could reveal the extent, types, and social patterns of 'mental defect' among children. Previous research had found that "intelligence varied decidedly with social status," but only children identified as 'backward' had been studied. This study, in contrast, proposed to survey "one moderate-sized school in the city where every child in attendance might be given an exhaustive examination in the Binet-Simon Tests." The researchers were especially interested to discover "correlation between mentality, social status, sex, nutrition and other factors supposedly related." The aims of the study were ambitious and forwardlooking: "To amass and systematise data which might later furnish ground for a thorough and consecutive programme of investigation into the efficiency of the children when they enter industrial life" (Pratt, 1921, p. 96).

Pratt described how, prior to this study, 'mental investigations' had been conducted on 60,000 pupils in Toronto schools (as part of Public Medical Inspection of Elementary School students). These investigations had revealed that "over a thousand children were found to be so mentally defective as to be absolutely incapable of making any progress in the classroom" (p. 95). However, it was another group of children that drew the attention of Pratt and his team. These where children who, although not strictly 'mentally defective,' were unable to keep up with "the normal advance of the pupils in their own class," thus demanding a disproportionate share of the teacher's time and attention, reducing her efficiency. Pratt and his colleagues suggested that the problems presented by these children - deemed "mentally abnormal," but yet to be scientifically identified and classified - were so complex and so urgent "that there shall be no arbitrary limitations imposed upon the mode of investigation" of their condition. He continued that these children "must be studied from all relevant standpoints." Thus, the researchers suggested it was important to study children's classroom and playground behavior in order to identify those exhibiting "moody isolation," "explosive and irresponsible conduct," or "sullenness, obstinacy 
and resentment" (Pratt, 1921, p. 95). The observing gaze was not limited to the classroom and schoolyard, however, as the children "must be viewed in relation to records of personal and personal history” (p. 96). While children's 'intelligence' was seen as important indicators of their capacity, they seemed to doubt the adequacy of the 'narrow meaning' of this measure, thus requiring more sociological observations to be useful in the predicting and planning of educational interventions. There remains then the factor which, with a somewhat narrow meaning, has been "usually described as psychological, namely, the intelligence of the child as determined by norms constructed out of the mental performances of other children of approximately the same physical age. This factor, insufficient by itself, may yet as a result of a standardized procedure be regarded as one of the most valuable single contributions to the diagnosis" (p. 96).

By way of a division of students into three social groups, as determined by fathers' occupation, Pratt wrote that the "social character of the district" surrounding the selected school was "a little below average" compared to the rest of the city, with $45 \%$ described as labourers (Class C), 52\% as artisans (Class B), and 3\% as professionals (Class A). Numerical representations of children's 'intelligence quotients' were then correlated with this hierarchical ranking of 'social status,' producing results that were, it seemed, both alarming and predictable: children whose fathers were labourers contributed disproportionally to groups labeled 'retarded' or 'defective,' while children of professionals were more likely to be labeled 'brilliant.' The numerical representations of 'intelligence' were mobilized to assert what the researchers 'found':

The figures here are quite significant. The professional class furnish no mental defect at all and no retardation below 80; nothing between 86 and 90 and only 2.6 between 81 and 85 which makes an almost negligible quantity over the whole range. On the other hand they furnish $15 \%$ - five times their proportionate share - of those between 121 and 125, and 29 - nearly ten times their share - of the brilliant quotients over 125. (Pratt, 1921, p. 100)

The correlation of different kinds of 'facts' and measures is asserted as authoritative, as Pratt continues to write that children in 'Class B' "furnish less than their share of defect and retardation.... and in the upper grades they furnish more than their share." But it was 'Class C' that was the main cause of concern: "Class C furnish $50 \%$ more than their share to mental defect (that is, 22 of 45 is slightly more than one-half), and more to the other subnormal groups with the exception of the 81-85 class; and in the upper grades their contribution is always less than their share, the difference amounting to one hundred per cent in the last two classes combined" (p. 100).

The paper continues to correlate measures of children's performance on intelligence tests with gender (elementary age boys performed slightly better than girls) and malnutrition (deemed 'too difficult' to determine or explain), and then launches into a description of particular 'cases' at both ends of the intelligence scale, contrasting those measuring "below IQ 75" and those who scored "above 130." Here the 
apparent facticity of numbers representing 'intelligence' collide with more mundane observations and moral judgments. Cases at the 'low' end were described in rather non-scientific terms: anemic, nasal trouble, poor vision, inert, weak-willed, defective palate, heavy, lethargic face, lazy, depressing home life, school attendance good or poor. In contrast, children measuring over 130 IQ were described as: alert, good attendance, good reasoning ability, reliable, healthy, very intelligent, good attendance, well behaved, alert and industrious, good home conditions. Pratt (1921) concluded that "anyone could see that leadership in industrial and professional life lay strongly embedded in such promising types" (p. 104). Indeed, to confirm such speculations, Pratt argued that great benefit could be derived if age cohorts tested as children were to be followed into the future. However, he also acknowledges that although such a study would be "vital," it is "a much more extended objective" than the present study. The paper ends with a detailed table, extending over 11 pages, in which the left column lists the names of every child in the school, and rows across present the child's grade level, age in months, nationality, IQ, Father's Occupation, and Stigmata.

At one level, the table, and the other types of 'data' reported on in Pratt's paper, can tell us something about the intentions and actions of scientists, and the kinds of knowledge that were assembled in order to know children in this period. The study brought together perspectives from medicine, psychology, and mental measurement, as well as more ordinary observations of habits and conduct. The persuasive power of numbers and tables is supplemented by narratives of particular cases in order to present 'evidence' of problems that must be made visible and that require intervention. At another level, we must ask how such 'evidence' was used and to what end. While Pratt and his colleagues were looking to test and track children into the future, school administrators and teachers used the research to identify children who should be removed from regular classrooms and placed into auxiliary programs. As this and similar studies were conducted in Toronto and other cities, urban school systems were creating programs that differentiated among students based on a range of physical disabilities, mental conditions, delinquency, and so on. Pratt's study thus joined others to produce scientific rationales for practices that would categorize and divide student populations. At the same time, other versions of psychology and psychiatry were also developed and applied in schools, including versions of child study and more child-centred forms of observation associated with Dewey's branch of progressive education.

One such approach to the psychology of childhood emerged in North American universities the 1920s and 1930s, enabled by large grants from the Laura Spelman Rockefeller Foundation. The University of Toronto was one among a handful of institutions selected by the Foundation to establish an institute focused on the mental hygiene of children (Raymond, 1991, pp. 20-21; Richardson, 1989). William E. Blatz was recruited to become the first Director of the St. George's Institute for Child Study in 1926. Born and Raised in Hamilton, Ontario, Blatz first completed a medical degree in Toronto, then studied for his $\mathrm{PhD}$ with Harvey Carr at the University of Chicago. Carr, in turn, had worked there with John Dewey (Raymond, 1991, pp. 20-21). According to his colleagues and students, Blatz was a charismatic 
and engaging speaker whose 'progressive' psychology and educational aims seemed radically at odds with the kind of research pursued by Pratt's study and its preoccupations with mental measurement and classification (Bernhardt, 1951). The pre-school program organized in the Institute for Child Study, and in the Windy Ridge elementary school that was later linked with it, emphasized a carefully organized environment where children would learn and develop through freely chosen activities, albeit structured through consistent routines and continuing observation. It is important to note that while Pratt's study aimed to examine the entire population of students in a public school, and to identify individuals who deviated from psychological norms, the children enrolled in the Institute for Child Study's nursery and elementary school programs were recruited from professional and middle-class families. During its first few years, parents - in practice, this meant mothers - were required to take part in an extensive program in parent education. Here, it was hoped, mothers would learn the importance of adopting the Institute's practices, thus fostering a program of 'security' and mental hygiene reaching from the nursery to the family (Raymond, 1991). ${ }^{8}$

The children in the Institute's programs, and their parents, were not only enrolled in a school, they were also 'subjects' in research on child psychology and child development. Indeed, research was the important third component of the Institute's work, and during the late 1920s and early 1930s, a large number of research reports, papers, and theses were produced by its staff and students (Bernhardt et al., 1951, pp. 93-178). Although intelligence tests were routinely administered in the Institute for Child Study's programs, their results were not used to determine children's educational potential or limitations. The kind of psychology generated through the Institute's research program was not so much concerned to determine children's intellectual abilities or cognitive capacities. Rather, their 'functional' or 'environmental' approach to studying children sought to identify the environmental conditions and social interactions (including relations with parents and teachers) that would nourish children's sense of security, viewed as a foundation for future autonomy, maturity, responsibility, and mental health (Volpe, 2010; Winestock, 1994). However, although the program sought to engender 'development' through children's 'natural' dispositions toward activity and play without adult intervention, it was comprised of tightly structured routines designed to instill regular habits. Moreover, children in this and similar programs were under constant observation - indoors and in the playground, whether playing, sleeping, eating, washing, or going to the bathroom - and any unexpected or difficult behaviour was duly recorded. As Varga (2011) notes, the observations generated through these institutes were assembled, analyzed, and represented as the truth about the child and its development, a truth that tautologically identified white, middle-class, and (most often) male children with the norm of healthy development.

Although the programs of the Toronto Institute for Child Study did not enroll a wide range of children, there were two occasions when its programs were applied to 'other' children. The first was during the mid-1930s when William Blatz was placed in charge of the care and education of the famous Dionne Quintuplets, born near North Bay, Ontario, in May 1934 (Dehli, 1995). The second opportunity to apply its methods beyond the select group of children in the St. George program arose in 
1942, when Blatz was asked to establish a training program for 'child care reservists' in Birmingham, England. The reservists were preparing to staff nursery centres being set up all over England, in turn allowing mothers to join war production (Prochner \& Howe, 2001). Blatz's association with the Quintuplets made him - and his controversial and 'progressive' methods of childrearing - world famous in the public media (Raymond, 1991), yet it did little to build his reputation among psychologists, some of whom felt that his flamboyant style and search for popularity suggested he was not a serious scientist. ${ }^{9}$ As well, the exciting promise presented to developmental psychology by the five identical Dionne girls was never realized, and Blatz's engagement with them only lasted a couple of years. In his final book, published two years after his death in 1964, he reflected on what he head learned in different periods of his life. The section about his involvement with Dionne Quintuplets is very short: "The growth of intelligence is largely due to an inherited factor. Personality is largely a matter of social patterns. It is acquired and only incidentally inborn” (Blatz, 1965, p. 8).

In contrast to Canada during the Depression years, the urgency of the Second World War and the need for staff to run nursery centres in England created conditions that proved more conducive to the Institute's approach. During its two years in operation, Garrison Lane, the nursery school and staff-training program that Blatz and his team established in the centre of Birmingham, trained hundreds of women. In part as a result of the fame he achieved through the Dionne Quintuplets, Blatz was much sought after as a public speaker and he gave dozens of lectures and media interviews. The program in Birmingham was visited by a steady stream of teachers, school inspectors, administrators, journalists, and public figures (Blatz, 1942, 1944). The demonstration nursery school attracted particular attention and, as in Toronto, the children could be discretely viewed through glass windows from an observation gallery.

Located in a working class area of Birmingham, Garrison Lane had been the site of a primary school that was damaged by bombs early in the War. It was quickly restored in preparation for the arrival of the first group of children and trainees in July 1942. Working in the Garrison Lane nursery offered important learning experiences for Millichamp, who appreciated the opportunity "to work with children who were not academically and intellectually ready for school." Her colleague Mary Wright, also interviewed by Prochner and Howe in 2001, reminisced about how working in Birmingham, and observing the effects of the nursery program on Garrison Lane children, persuaded her that this approach to early childhood education would benefit all children, and especially those deemed 'underprivileged' (Prochner \& Howe, 2001, p. 23). ${ }^{10}$ Later accounts by some of the nursery program staff suggested that they expected that the children enrolling in the Birmingham program would be quite unlike those they encountered in Toronto. In an interview conducted by Prochner and Howe in 2001, Dorothy Millichamp recalled: "Garrison Lane was really our first experience at applying the Institute's theory, principles, and practices to a group of under-privileged children" (p. 23). As she continued her account, Millichamp constructed an image of children who were "very poor" and different and who required support "to live in a nursery school and to develop all kinds of learning patterns." 
The children's difference was identified through comparison, by noting what they lacked - for example, "conventional eating habits," and an ability "to play with typical nursery school materials." Yet, there is a note of irony when she commented on what would count as conventional and typical: "We had to introduce them to play, which meant a lot more adult intervention and a lot more adult participation than we were doing with our very 'normal' children from highly educated families at the Institute's nursery school back in Toronto" (p. 23). Millichamp's reflection suggests perhaps that she was aware that the Institute's construction of 'normal' childhood was based on observation of a rather select group of children. Nevertheless, her account relies on comparisons of groups of children according to notions of 'normal' that, in turn, were crafted in terms of children's adjustment to, or readiness for, schooling.

In addition to observing changes in their habits of play, sleep, eating, and defecating, Millichamp and Wright described how children in the Garrison Lane program, like those at the Institute in Toronto, were regularly subjected to Stanford-Binet tests of 'intelligence': "We were testing the Garrison Lane children, and one of the interesting things was how their IQs were coming up. In other words, they were not mentally retarded children, but they were mentally undeveloped children who had a long way to go" (Prochner \& Howe, 2001, p. 23). Reading their scores on the Stanford-Best test that Wright regularly applied suggested to the staff that their program had a marked effect of the children's 'intelligence.' Furthermore, they felt that these results could demonstrate that 'intelligence' was stimulated, or constrained, by environmental factors, and that it could be nurtured through early education. According to Dorothy Millichamp, the Institute staff was 'steamed up' by the results and the implications they could have for education policy. They were, in her words, "eager to promote their brand of nursery education as beneficial for all children" (p. 22). Some years earlier, Beth Lucy Wellman of the Iowa Child Welfare Research Station had presented a series of studies that showed similar patterns of improvement over time in responses to intelligence tests among children who attended nursery school, while 'deprived environments' could lead to 'IQ loss.' Rather surprised by these results, Wellman and her colleagues suggested that 'intelligence,' as measured by scores on tests, was shaped by environment and stimulation, rather than fixed in biology (Russo, 1983, p. 12; Winestock, 1994, p. 352). In the 1930s, this was a very controversial claim, contrary to a widely accepted truth that heredity trumped culture or environment, and the Iowa research was met with dismissal and hostility from many established psychologists and educators (Crissey, 1990; Richardson, 1989, pp. 135-136).

Blatz, Millichamp, Wright, and other colleagues at the Institute for Child Studies were, of course, familiar with these controversies. And yet, aside from a very short and inconclusive discussion toward the end of Blatz's 1944 book, Understanding the Young Child, no papers were published based on these discoveries, nor was any follow-up study conducted with children attending the Garrison Lane program (Prochner \& Howe, 2001). In this paper I can only speculate why so little was made of research that could have bolstered claims about the benefits of early childhood education. It might be that the Institute staff were simply too busy or too focused 
on the work of training nursery school personnel to embark on a more careful and encompassing study of the children's intelligence; or it might be that Blatz was not much interested in making discoveries about 'intelligence' and rather focused on questions of 'personality' and 'security,' or it may be that in the context of war, the aim of 'child development' turned to nurturing individuals who as adults would be inclined toward social responsibility and democratic citizenship (Bernhardt, 1951, pp. 3-9).

In her genealogies of child development Valerie Walkerdine has argued for a critical reading of psychology that is not about contrasting true scientific stories versus false popularizations or pseudo-science, nor is it about arguing that psychology is a form of ideology that distorts or obscures "true and proper stories about children." Rather, she is interested in showing how psychology, and child development in particular, is engaged in "actually producing, fashioning 'the child' and 'development" as objects of knowledge and targets of intervention and regulation. Walkerdine (1993) argues that "these objects are not simply well or badly represented but actually produced within signifying relations themselves" (p. 452). With regard to the examples I have discussed in this paper, it would be tempting to suggest that Pratt's survey and measurement of children's 'mentalities' exemplify 'bad' stories and misguided research that were in time replaced by more enlightened and progressive forms of observation and intervention. That is not a claim that I would want to make. Instead, I have discussed these examples in order to highlight the means and techniques that were fashioned to bring 'the child' into the new truths of psychological and educational knowledge in the first half of the twentieth century. In these local examples, I wanted to trace entanglements of practices, which identified some children as normal, and many others as deficient, and also to show how psychological forms of observation that we today take for granted were brought into being. Following Rose and Walkerdine, one could argue that the early decades of the 20th century, the nexus of urban education and poverty brought into view populations that were constituted as particular kinds of pedagogical and administrative problems. One strand of psychology sought to locate those problems in children's minds, as demonstrated on their responses to tests of 'intelligence,' while child study was concerned with observations and production of 'normal' children. The programs established in Toronto and Birmingham by Blatz and his colleagues were very explicit about their aims in this regard, as they detailed how space and time should be organized, and how pedagogies should be approached as a form of detached observation. One might want to conclude that one psychological approach is better and more progressive than the other, that one asserted classifications that had profound effects on children, while the other offered promises of improvement and change. Such narratives are quite familiar in histories of psychology and early childhood education. The problem is not so much that these accounts are 'wrong,' but that they take the 'child' and 'development' as given, as natural and obvious categories against which actual children are compared and many are found wanting.

In the examples I have discussed in this paper, I have tried to show how different forms of psychological knowledge and practice brought particular versions of the 
'child' into view. I do not believe that we can rely on internal histories of psychology to uncover the evolution of psychological objects, nor to reveal the 'true nature' lying beneath chimera of ideological representations. As Lisa Blackman (1994) has argued, the psychological object does not pre-exist observation and categorization (p. 486), and the work of 'doing history' is therefore to trace how such objects come into being through the very practices of observation and categorization.

\section{Notes}

1. See also Rose, N. (2001). The politics of life itself. Theory, Culture \& Society, 18(6), 1-30.

2. For an excellent discussion of some of the tensions surrounding 'Foucault' in education research, see Coloma, R. S. (2011). Who's afraid of Foucault? History, theory, and becoming subjects. History of Education Quarterly, 51(2), 184-210. For another take on these debates, see Popkewitz, T. S. (Ed.). (2013). Rethinking the history of education: Transnational perspectives on its questions, methods, and knowledge. New York, NY: Palgrave Macmillan.

3. For summary of these positions, see Richardson, T. R. (1989). The century of the child: The mental bygiene movement \& social policy in the United States and Canada. Albany, NY: State University of New York Press.

4. See for example, Sutherland, N. (1976). Children in English-Canadian society: Framing the twentieth-century consensus. Toronto, ON: University of Toronto Press; Gleason, M. (1999). Normalizing the ideal: Psychology, schooling, and the family in postwar Canada. Toronto, ON: University of Toronto Press; Commachio, C. (1993). Nations are built of babies: Saving Ontario's mothers and children 1900-1940. Montreal, QC, and Kingston, ON: McGill-Queen's University Press; Pols, H. (2002). Between the laboratory and life: Child development research in Toronto, 1919-1956. History of Psychology, 5(2), 135-162; Varga, D. (1997). Constructing the child: A bistory of Canadian day care (an Our Schools/Our Selves title). Toronto, ON: James Lorimer \& Company.

5. See also Rose, N. (1999). Governing the soul: The shape of the private self (2nd ed.). London, England: Free Association Books.

6. In addition to Rose and Walkerdine, a number of education scholars have incorporated Foucault's analytical approaches into their work. Among them, the essays in Changing the Subject (1984) had an important impact on my thinking about education. See Henriques, J., Hollway, W., Urwin, C., Venn, C., \& Walkerdine, V. (Eds.). (1984). Changing the subject: Psychology, social regulation and subjectivity. London, England: Methuen. See also Ball, S. J. (Ed.). (1990). Foucault and education. London, England: Routledge; Scheurich, J. (1994). Policy archaeology: A new policy studies methodology. Journal of Education Policy, 9(4), 297-316; Popkewitz, T. S., \& Brennan, M. (Eds.). (1998). Foucault's challenge: Discourse, knowledge, and power in education. New York, NY: Teachers College Press; Ball, S. J., \& Tamboukou, M. (Eds.). (2003). Dangerous encounters: Genealogy and ethnography. New York, NY: Peter Lang; Baker, B., \& 
Heyning, K. L. (Eds.). (2004). Dangerous coagulations? The uses of Foucault for the study of education. New York, NY: Peter Lang; Olssen, M. (2006). Michel Foucault: Materialism and education. Boulder, CO, and London, England: Paradigm Publishers.

7. Pratt attended the founding of the CNCMH in 1918, joined by several colleagues and the president of the University of Toronto, as well as the City's Medical Officer of Health, the Province's Director of Programs for the Feeble-minded, and leaders of Toronto's women's movement. That meeting was also attended by Clifford Beers of the American Committee for Mental Hygiene, whose recognized expertise lent authority to the new organization. See McConnachie, K. J. A. (1987). Science and ideology: The mental bygiene and eugenics movements in the inter-war years, 1919-1939. (Doctoral dissertation). University of Toronto, ON; and Richardson (1989).

8. See also discussion in Wright, M. J. (2010). W.E. Blatz: The person and his work. In R. Volpe (Ed.), The secure child: Timeless lessons in parenting and childhood education (pp. 15-41). Charlotte, NC: Information Age Publishing; and Winestock, S. L. (1994). William Emet Blatz: The development of a developmental psychologist. (Doctoral Thesis). York University, Toronto, ON.

9. For further discussion, see Volpe (2010), Whitehead (1994), and Dehli (1995).

10. See also Wright, M. J. (2010). The secure pre-schooler: Nurturing creativity with courage, wisdom with responsibility. Canadian Psychology, 51(4), 231-240; Ball, L. (2010). Profile of Mary Jean Wright. In A. Rutherford (Ed.), Psychology's feminist voices multimedia internet archive. http://www.feministvoices.com/mary-jean-wright/

11. For critical reading of such histories, see Bloch, M. N. (1991). Critical science and the history of child development's influence on early education research. Early Education and Development, 2(2), 95-108.

\section{References}

Addams, J. (1912). Twenty years at Hull-House with autobiographical notes. New York, NY: The MacMillan Company.

Bernhardt, K. S. (1951). A prophet not without honour: The contribution of William

E. Blatz to child study. In K. S. Bernhardt, M. I. Fletcher, F. L. Johnson, D. A.

Millichamp, \& M. L. Northway (Eds.), Twenty-five years of child study: The development of

the programme and review of the research at the Institute for Child Study, University of Toronto,

1926-1951. Toronto, ON: University of Toronto Press.

Bernhardt, K. S., Fletcher, M. I., Johnson, F. L., Millichamp, D. A., \& Northway, M. L.

(Eds.). Twenty-five years of child study: The development of the programme and review of the research at the Institute for Child Study, University of Toronto, 1926-1951. Toronto, ON: University of Toronto Press.

Blackman, L. (1994). What is doing history? The use of history to understand the constitution of contemporary psychological objects. Theory \& Psychology, 4(4), 485-504. http:// dx.doi.org/10.1177/0959354394044002 
Blatz, W. E. (1944). Understanding the young child. New York, NY: William Morrow \& Company.

Blatz, W. E. (1965). Human security: Some reflections. Toronto, ON: University of Toronto Press.

Blatz, W. E., to Hincks. (1942, October). Wartime Nursery Schools, Parent Education Bulletin No. 19. Blatz (W.E.) Collection, MS. Coll. 134, Thomas Fisher Rare Book Library, University of Toronto.

Bruer, J. T. (1999). In search of...Brain-based education. Pbi Delta Kappan, 80(9), 648-657.

Burman, E. (2005). Engendering culture in psychology. Theory \& Psychology, 15(4), 527-548. http://dx.doi.org/10.1177/0959354305054750

Corrigan, P., \& Sayer, D. (1985). The great arch: English state formation as cultural revolution. Oxford, England: Blackwell.

Crissey, M. S. (1990). Beth Lucy Wellman (1895-1952). In A. N. O'Connell \& N. F. Russo (Eds.), Women in psychology: A bibliographic sourcebook (pp. 350-359). Westport, CT: Greenwood Publishing Group.

Curtis, B. (1992). True government by choice men? Inspection, education, and state formation in Canada West. Toronto, ON: University of Toronto Press.

Danziger, K. (1997). Naming the mind: How psychology found its language. London, England: Sage Publications Ltd.

Dehli, K. (1988). Women and class: The social organization of mothers' relations to schools in Toronto, 1915-1940. (Doctoral thesis). University of Toronto, ON.

Dehli, K. (1990). Health scouts for the state? School and public health nurses in early twentieth-century Toronto. Historical Studies in Education, 2(2), 247-264.

Dehli, K. (1995). Fictions of the scientific imagination: Researching the Dionne quintuplets. Journal of Canadian Studies, 29(4), 86-110.

Dehli, K. (1996, September). Love and knowledge: Adult education in the Toronto Home and School Council, 1916-1940. Ontario History, 88(3), 207-228.

Donaldson, M. (1979). Children's minds. New York, NY: Norton.

Gazzaniga, M.S. (2005). The ethical brain. New York, NY: Data Press.

Grosvenor, I., \& Myers, K. (2006). Progressivism, control and correction: Local education authorities and educational policy in twentieth-century England. Paedagogica Historica, 42(1 \& 2), 225-247. http://dx.doi.org/10.1080/00309230600552153

Hareven, T. K. (1969, April). An ambiguous alliance: Some aspects of American influences on Canadian social welfare. Histoire Sociale/Social History, 3, 82-98.

Hunter, I. (1996). Assembling the school. In A. Barry, T. Osborne, \& N. Rose (Eds.), Foucault and political reason: Liberalism, neo-liberalism and rationalities of government (pp. 143166). Chicago, IL: University of Chicago Press.

Lee, N., \& Motzkau, J. (2011). Navigating the bio-politics of childhood. Childhood, 18(1), 7-19. http://dx.doi.org/10.1177/0907568210371526

McCain, M., \& Mustard, F. (1999). The early years study - Reversing the real brain drain. Toronto, ON: Publications Ontario.

Milewski, P. (2010). The scientisation of schooling in Ontario: 1910-1934. Paedagogica Historica, 46(3), 341-355. http://dx.doi.org/10.1080/00309230903202241

Ontario Ministry of Education. (2013). Ontario Early Years Policy Framework. http://www.edu. gov.on.ca/childcare/OntarioEarlyYear.pdf 
Pascal, C. E. (2009). With our best future in mind: Implementing early learning in Ontario. Report to the Premier by the Special Advisor on Early Learning. Toronto, ON: Government of Ontario.

Paterson, F. M. (1989). Out of place: Public policy and the emergence of truancy. London, England: Falmer Press.

Pols, H. (2002). Between the laboratory and life: Child development research in Toronto, 1919-1956. History of Psychology, 5(2), 135-162. http://dx.doi. org/10.1037/1093-4510.5.2.135

Pratt, E. J. (1921, April). The application of the Binet-Simon tests (Stanford revision) to a Toronto public school. Canadian Journal of Mental Hygiene, 3(1), 95-116.

Prochner, L., \& Howe, N. (2001). The wartime child care centres in Canada and Great Britain: The 60th anniversary. Canadian Children, 26(2), 21-27. http://www. peelearlyyears.com/pdf/TheWartime Child Care Centres in Canada and Great Britain. pdf

Raymond, J. M. (1991). The nursery world of Dr. Blat: Toronto, ON: Unversity of Toronto Press.

Richardson, T. R. (1989). The century of the child: The mental bygiene movement \& social policy in the United States and Canada. Albany, NY: State University of New York Press.

Rose, N. (1979, Spring). The psychological complex: Mental measurement and social administration. Ideology \& Consciousness (5), 5-68.

Rose, N. (1985). The psychological complex. London, England: Routledge and Kegan Paul.

Russo, N. F. (1983). Psychology's foremothers: Their achievements in context. In A. N. O'Connell \& N. F. Russo (Eds.), Models of achievement: Reflections of eminent women in psychology (pp. 9-24). New York, NY: Columbia University Press.

Varga, D. (2011). Look-normal: The colonized child of developmental science. History of Psychology, 14(2), 137-157. http://dx.doi.org/10.1037/a0021775

Vidal, F. (2009). Brainhood: Anthropological figure of modernity. History of the Human Sciences, 22(1), 6-35. http://dx.doi.org/10.1177/0952695108099133

Volpe, R. (Ed.). (2010). The secure child: Timeless lessons in parenting and childhood education. Charlotte, NC: Information Age Publishing.

Walkerdine, V. (1984). Developmental psychology and the child-centred pedagogy: The insertion of Piaget into early education. In J. Henriques, W. Hollway, C. Urwin, C. Venn, \& V. Walkerdine (Eds.), Changing the subject: Psychology, social regulation and subjectivity. (pp. 153-202). London, England: Methuen.

Walkerdine, V. (1993). Beyond developmentalism? Theory \& Psychology, 3(4), 451-469. http:// dx.doi.org/10.1177/0959354393034004

Winestock, S. (1994). William Emet Blat:: The development of a developmental psychologist. (Doctoral Thesis). York University, Toronto, ON. 